УДК 620.92

\title{
АНАЛІЗ КРИТЕРІЇВ СТАЛОГО РОЗВИТКУ БІОЕНЕРГЕТИКИ
}

\author{
Гелетуха Г.Г., канд. тех. наук, Желсзна Т.А., канд. тех. наук, Трибой О.В.,
}

Баштовий А.I., канд. тех. наук

Інститут технічної теплофізики НАН Украӥни, вул. Желябова, 2а, Київ, 03680, Україна

Проаналізовано критерії сталості Євросоюзу для виробництва та використання біопалив. Розглянуто поточну політику $\mathrm{CC}$ щодо сталості біоенергетики та плани на майбутній період. Показано, що загалом в Європі спостерігається тенденція поступового посилення вимог щодо виконання критеріїв сталості. Представлено рекомендації для України по запровадженню сталого виробництва біопалив.

Бібл. 15.

\begin{abstract}
Проанализированы критерии устойчивости Евросоюза для производства и использования биотоплив. Рассмотрена текущая политика ЕС по устойчивости биоэнергетики и планы на будущий период. Показано, что в целом в Европе наблюдается тенденция постепенного ужесточения требований по выполнению критериев устойчивости. Представлены рекомендации для Украины по внедрению устойчивого производства биотоплив.
\end{abstract}

EU sustainability criteria for the production and consumption of biofuels are analyzed. The paper reviews current EU policy on sustainable bioenergy and future plans. It is shown that general trend is appearance of wider and stricter requirements for the sustainability of biofuels. Recommendations for the sustainable production of biofuels in Ukraine are presented.

Ключові слова: сталий розвиток, критерії сталості, біоенергетика, біомаса, тверде біопаливо, рідке біопаливо.

ВДЕ - відновлювані джерела енергії;

ГБП - Глобальне біоенергетичне партнерство;

ДСС - добровільна схема сертифікації;

ККД - коефіцієнт корисної дії;

ОЖЦ - оцінка життєвого циклу;

НПДВЕ - Національний план дій з відновлюваної

\section{Поняття сталого розвитку}

Питанню сталого розвитку суспільства в широкому сенсі цього поняття (захист довкілля та здоров'я людей, заміщення викопних палив альтернативними джерелами енергії, доступ до водних ресурсів та ін.) стала приділятися особлива увага після проведення так званого Саміту Землі у 1992 році у Ріо-де-Жанейро. Основними темами цієї конференції Об'єднаних Націй були захист навколишнього середовища та сталий розвиток. Результатом роботи Саміту стали розробка низки важливих документів (Декларація принципів ведення лісового господарства, Конвенція Об'єднаних Націй щодо біологічного різноманіття та ін.) та створення кількох міжнародних комісій з питань сталого розвитку.

Існують різні визначення поняття сталого енергетики;

ТЕС - теплова електростанція;

ТЕЦ - теплоелектроцентраль.

Нижній індекс:

т - тепловий;

е - електричний.

розвитку, але найчастіше використовують наступне: сталий розвиток - це розвиток, який задовольняє потреби нинішнього покоління без шкоди для можливості майбутніх поколінь задовольняти свої власні потреби [1]. Сталий розвиток має три компонента: економічний розвиток, соціальний розвиток та захист навколишнього середовища [2]. Вважається, що базова концепція сталого розвитку і стратегія його досягнення мають бути спільними для всіх країн. Натомість інтерпретації можуть відрізнятися в різних країнах, беручи до уваги їх соціальні, економічні та політичні особливості.

\section{Вимоги сталості до рідких та газоподібних моторних біопалив. Добровільні схеми сертифікаціі}

Сталий розвиток біоенергетики є невід'ємною 
складовою частиною загального процесу сталого розвитку суспільства в цілому і енергетики зокрема. Європейська Комісія приділяє велику увагу цьому питанню з акцентом на забезпечення сталого отримання біомасової сировини для виробництва біопалив та енергії. Деякі вимоги щодо цього вже є обов'язковими для країн-членів EC (виробництво рідких біопалив та біорідин для можливості зарахування у виконання цілі 2020 року по використанню ВДЕ на транспорті та для отримання фінансової підтримки), інші ще носять рекомендаційний характер (виробництво електричної енергії, теплової енергії та холоду 3 твердої та газоподібної біомаси). Загалом спостерігається тенденція поступового посилення вимог щодо виконання критеріїв сталості.

Наразі рамки сталості для рідких/ газоподібних моторних біопалив та біорідин на рівні ЄС забезпечують Директива про стимулювання використання відновлюваних джерел 2009/28/EC [3] (iз змінами та доповненнями 2015 року [4]) та Директива щодо якості транспортних палив 2009/30/СС [5]. Під біорідинами розуміється рідке паливо, отримане з біомаси, й призначене для енергетичних цілей, інших, ніж транспорт, в тому числі для виробництва електроенергії, теплової енергії й холоду.

Директивою 2009/28/ЄC поставлено обов'язкову ціль для Євросоюзу по досягненню щонайменше 10 \% ВДЕ у транспортному секторі до 2020 року. При цьому частка біопалив, вироблених $з$ харчових сільськогосподарських культур, має становити не більше 7 \% кінцевого енергоспоживання на транспорті, а для біопалив, отриманих з відходів, залишків, нехарчової целюлозної сировини та лігноцелюлозної сировини, робиться подвійне зарахування у виконання цілі 2020 року. Також зазначено, що виробництво моторних біопалив та біорідин має бути сталим, i тільки такі біопалива зараховуються до виконання поставленої цілі та можуть отримувати фінансову підтримку.

Для біопалив та біорідин визначено наступні обов’язкові критерії сталості [3, 4]:

- Скорочення викидів парникових газів від використання біопалив та біорідин має бути не менше $35 \%$ до 31.12.2017 і не менше $50 \%$ - 3 01.01.2018 для біопалив та біорідин, виробле- них на установках, які вже були в експлуатації до 05.10.2015 включно. Для установок, які розпочали роботу після 05.10.2015, мінімальне скорочення викидів парникових газів має становити $60 \%$.

- Біопалива та біорідини не повинні вироблятися з сировини, отриманої на землях з високим рівнем біорізноманіття (ліси та лісові площі, заповідні зони, біорізноманітні луки), а також на землях 3 високим запасом вуглецю (заболочені землі, ліси з визначеним рівнем покриву) і $з$ торфовищ.

Біопалива та біорідини, що виробляються iз відходів/залишків не сільськогосподарського чи лісогосподарського походження, мають задовольняти лише критерію сталості щодо скорочення викидів парникових газів.

Відповідно до положень Директиви 2009/28/ ЄC, країни ЄС вимагають від суб'єктів економічної діяльності підтвердження дотримання критеріїв сталості для біопалив/біопаливних рідин. Виконання критеріїв сталості може бути доведено трьома способами:

a) поданням пакету необхідних даних національному відповідальному органу згідно встановлених в країні правил, тобто за допомогою національної системи перевірки (верифікаціі);

б) застосуванням добровільних схем сертифікації (національних або міжнародних), визнаних Свропейською Комісією;

в) укладанням дво- або багатосторонніх угод, що містять необхідні умови щодо сталості, 3 третіми країнами, причому угоди мають бути визнані Єврокомісією.

Національна система перевірки відповідності критеріям сталості може грунтуватися на двох підходах [6]:

1. Використовуються тільки добровільні схеми сертифікації. Це можуть бути ДСС як визнані Єврокомісією, так і схвалені самою країною на відповідність положенням Директиви 2009/28/ ЄС. Принаймні 8 країн ЄС впровадили такий варіант національної системи перевірки (Бельгія, Чеська Республіка, Естонія, Німеччина, Литва, Нідерланди, Швеція).

2. Система включає як ДСС, так і принцип «самозвітування» зобов'язаними сторонами (головним чином - постачальниками біомаси, виробниками біопалив). Самозвітування означає, 
що постачальник/виробник може самостійно подавати «докази» виконання критеріїв сталості до відповідального адміністративного органу, а не через застосування ДСС. Близько 12 країн ЄС дозволяють принцип самозвітування у своїх національних системах (Австрія, Хорватія, Данія, Франція, Угорщина, Ірландія, Італія, Латвія, Мальта, Португалія, Румунія, Словаччина, Великобританія).

Наразі найбільш розповсюдженим варіантом демонстрації відповідності критеріям сталості $€$ використання добровільних схем сертифікації, визнаних Європейською Комісією. Певна ДСС може бути визнана Сврокомісією, якщо іï принципи задовольняють наступним умовам:

- виробництво біомасової сировини відповідає критеріям сталості;

- вся інформація щодо характеристик сталості ретельно задокументована i простежується до джерела сировини;

- перед подачею документів на ДСС компанії проходять аудит, а також регулярно виконуються аудити, що мають зворотну силу;

- аудитори є зовнішніми та незалежними, а також мають загальні та спеціальні кваліфікації, що стосуються критеріїв сталості певної схеми.

На сьогодні Європейською Комісією визнано 19 добровільних схем сертифікації, період визнання становить 5 років. Повний перелік схем сертифікації можна знайти на веб-сайті Європейської Комісії [7], порівняльний аналіз найбільш розповсюджених ДСС представлений в роботі [8]. Всі схеми сертифікації мають свої особливості, переваги та недоліки, тому до вибору оптимальної ДСС необхідно підходити індивідуально в кожному конкретному випадку.

У 2012 році було прийнято загальноєвропейський стандарт EN 16214: Критерії сталості для виробництва біопалив та біорідин для енергетичного використання - принципи, критерії, показники та верифікація [9]. Стандарт складається 3 чотирьох частин: 1 - Термінологія, 2 - Оцінка відповідності, включаючи ланцюжок постачання та масовий баланс (цю частину було оновлено у 2014 р.), 3 - Біорізноманіття та аспекти, пов'язані із захистом довкілля, 4 - Методи розрахунку балансу емісії парникових газів 3 використанням оцінки життєвого циклу.
Вимоги сталості до твердих та газоподібних біопалив в секторі виробництва електроенергії, теплової енергії та холоду.

Якщо вимоги сталості для моторних біопалив та для біорідин вже є обов'язковими для виконання в СС, то критерії сталості для твердих та газоподібних біопалив в секторі виробництва електроенергії, теплової енергії та холоду ще мають рекомендаційний характер.

Згідно вимог Директиви 2009/28/€C, Європейська Комісія у 2010 році підготувала звіт Раді та Свропарламенту [10], в якому проаналізовано, які саме вимоги сталості потрібно застосовувати для твердих/газоподібних біопалив для виробництва електроенергії, теплової енергії та холоду, і чи мають вони бути обов'язковими. У звіті зазначено, що чинне законодавство Свропейського Союзу щодо сільського та лісового господарства (наприклад, Сдина сільськогосподарська політика, Стратегія ЄС в секторі лісового господарства) та деякі інші документи (наприклад, матеріали Міністерської Конференції по захисту лісів в Свропі) певною мірою забезпечує сталість отримання біомаси у цих секторах. Але $є$ необхідність у єдиній системі сталості, яка сприятиме подоланню «міжкордонних» бар'єрів в СС при впровадженні біоенергетичних проектів.

У звіті Свропейської Комісії визначено чотири аспекти забезпечення сталості використання твердих та газоподібних біопалив для виробництва електроенергії, теплової енергії та холоду [10]:

1. Сталість виробництва біомаси (землевпорядкування, вирощування та збирання біомаси). Зокрема, це стосується захисту екосистем 3 високим рівнем біорізноманіття та великим запасом вуглецю (наприклад, ліси). В СС ризик несталого виробництва біомаси наразі оцінюється як низький, оскільки більша частина біомаси походить $з$ відходів лісового господарства та деревообробної промисловості, а лісокористування відповідає стандартам високого рівня. Однак розширення ресурсної бази за рахунок біопалив, отриманих поза межами $\mathrm{CC}$, вимагає підвищення пильності до аспекту сталості.

2. Проблема зниження запасу вуглецю через зміну виду землекористування та збезлісення. Необхідно забезпечити належний облік емісії ву- 
глецю, пов'язаної з цими процесами.

3. Баланс парникових газів може бути розрахований згідно методології оцінки життєвого циклу. Оскільки ця методологія є досить гнучкою і дає можливість визначати межі окремо для кожного конкретного дослідження, це може вплинути на результати розрахунку балансу парникових газів для біоенергетичних технологій. Тому вважається доцільним дотримуватися методологічних рекомендацій ОЖЦ, наведених для моторних біопалив та для біорідин в Директиві 2009/28/СС. Проте, через деяку відмінність ланцюжків життєвого циклу рідких та твердих/газоподібних біопалив, необхідно розширити межі прийнятої Директивою 2009/28/ ЄС методології ОЖЦ для врахування конверсії біопалива в електроенергію, теплову енергію чи холод.

Досвід Європи показує, що при використанні твердих біопалив, отриманих в СС 3 відходів сільського або лісового господарства, зниження викидів парникових газів у порівнянні із застосуванням викопних палив становить зазвичай більше 80 \%. Цей показник набагато вищий, ніж для моторних біопалив, оскільки типова технологічна операція виробництва твердого біопалива (наприклад, гранулювання) як правило менш енергоємна, ніж операції отримання транспортних біопалив.

4. Ефективність енергетичної конверсії. Зниження енергоспоживання та підвищення ефективності виробництва енергії $є$ одними 3 пріоритетних цілей Євросоюзу. Беручи до уваги поточні ККД енергоустановок на біомасі (побутові пічки та котли $10 \ldots 95 \%$, ТЕЦ та котельні системи централізованого теплопостачання $80 \ldots 90 \%$, TEC $10 \ldots 35 \%$ ), можна констатувати, що існує великий потенціал зменшення енергоспоживання за рахунок підвищення ефективності енергоконверсії. Розглядаючи сировину, для якої можливі кілька варіантів енергоконверсії, необхідно віддавати перевагу технології з найвищою ефективністю перетворення енергіï.

Європейська Комісія рекомендує наразі застосовувати вимоги сталості до установок на твердій біомасі тільки потужністю $\geq 1 \mathrm{MBT}_{\text {т }}$ або $1 \mathrm{MBT}_{\mathrm{e}}$. Видається, що якщо вимагати підтвердження сталості від малих біоенергетичних установок (яких дуже багато), то це призведе до створення необгрунтовано великого адміністративного тягаря, хоча й стимулюватиме покращення екологічних показників роботи установок.

Єврокомісія рекомендує країнам ЄC вести ретельний облік походження первинної біомаси, що використовується для виробництва електроенергії, теплової енергії та холоду установками потужністю $\geq 1$ МВт. Також рекомендується відстежувати застосування біомаси у малих установках (головним чином, побутових) шляхом проведення відповідних опитувань користувачів.

На виконання настанов Сврокомісії вже близько половини країн ЄС впровадили законодавче стимулювання високоефективних біоенергетичних установок (наприклад, ТЕЦ). Деякі країни (Бельгія, Італія, Великобританія) прийняли критерії щодо скорочення емісії парникових газів при використанні біомаси для виробництва теплової та електричної енергії, інші запровадили критерії сталого лісокористування для лісової біомаси (Бельгія, Угорщина, Великобританія) та критерії сталого землекористування для отримання сільськогосподарської біомаси (Великобританія).

Також ряд країн прийняли правила для уникнення потенційної конкуренції енергетичного використання біомаси 3 іншими існуючими напрямками застосування. Так, наприклад, у Бельгії (Фламандський регіон) деревина, придатна для деревообробної промисловості, не підпадає під дію системи «зелених» сертифікатів на електроенергію. У Польщі стимулююче законодавство у секторі ВДЕ не розповсюджується на стовбурову деревину більше певного діаметра.

Для деревної та сільськогосподарської біомаси Єврокомісія рекомендує принцип так званого каскадного (потокового) використання. Його суть полягає в тому, що одна і та ж біомаса може бути використана кілька разів. Наприклад, спочатку ділова деревина застосовується в будівництві, потім деревний лом - для виробництва продукції, яка не потребує сировини високої якості, а відходи виробництва - для отримання енергії. Хоча зазвичай енергетичне використання має знаходитися внизу цієї «ієрархії», визнається, 
що в ряді випадків це є єдиним економічно обгрунтованим варіантом утилізації біомасової сировини.

\section{Критерії сталості Глобального біоенергетичного партнерства}

Організація Глобальне біоенергетичне партнерство була заснована у 2006 році. Одна 3 ii основних цілей - сприяти сталому розвитку біоенергетики, особливо у країнах, що розвиваються. Наразі ГБП включає 23 країни (у тому числі Аргентина, Бразилія, Канада, Китай, США, Німеччина, Швеція, Великобританія) та 14 міжнародних організацій (у тому числі FAO, IRENA, UNDP, UNIDO). Ще 27 країн та 12 міжнародних організацій беруть участь у ГБП як спостерігачі.

У 2008 році Глобальне біоенергетичне партнерство створило робочу групу з питань сталого виробництва та використання енергії з біомаси. Ця група розробила науково-обгрунтований набір критеріїв сталості із 24 показників, рівномірно згрупованих по трьом напрямкам: екологічний, соціальний, економічний [11]. Для кожного показника представлено опис та детальну методологію його оцінки. Автори зазначають, що показники сталості ГБП не дають відповідей на всі можливі питання щодо сталості і не дають конкретних значень для критеріїв. Натомість вони адекватно окреслюють всі проблемні аспекти сучасного виробництва та використання енергії з біомаси, які країнам необхідно оцінювати для виконання своїх національних цілей зі сталого розвитку. Застосування показників є добровільним, кожна країна має індивідуально підходити до визначення необхідного набору показників сталості ГБП, беручи до уваги свої національні законодавчі та соціально-економічні фактори.

\section{Політика СС щчодо сталості біоенергетики після 2020 року}

У вересні 2015 р. Європейська Комісія оголосила, що до початку 2017 р. випустить нову Директиву з ВДЕ, що включатиме цілі для всіх країн-членів СС на період 2020-2030 pp. Метою $\epsilon$ скорочення викидів парникових газів у Євросоюзі на 40 \% відносно 2005 р. і досягнення, як мінімум, 27 \% ВДЕ в енергобалансі СС до 2030 р., а також запровадження політики сталості для біоенергетики [12].

В рамках консультацій Єврокомісії, які проходили протягом лютого-травня 2016 року, Європейська Асоціація Біомаси (AEBIOM), що об'єднує 29 національних асоціацій і 90 профільних компаній з усієї Європи, підготувала свої рекомендації щодо рамок сталої політики для біоенергетики. Дані рекомендації включають наступні ключові положення [13]:

- Формулювати принципи сталості, виходячи 3 типу і категорії біомаси, а не напрямків iii кінцевого використання. Наприклад, деревна тріска може використовуватись для виробництва теплової і електричної енергї, а також біопалив 2-го покоління.

- Встановити планку зі скорочення викидів парникових газів на рівні 60 \% для всього сектора біоенергетики.

- Розширити критерії сталого землекористування на всю первинну біомасу аграрного походження незалежно від напрямків іiі енергетичного використання.

- Враховувати ризики, пов'язані з використанням лісової біомаси, для гарантування того, що використання лісової біомаси в енергетичних цілях не несе негативного впливу на навколишнє середовище.

- Встановити поріг потужності для біоенергетичних установок, які мають доводити виконання критеріїв сталості. Це стосується установок, що виробляють теплову та/або електричну енергію $з$ твердих біопалив. Дослідження, проведені АЕВIОМ, показують, що хоча всього близько $15 \%$ всіх енергоустановок в СС мають потужність > 20 МВт (по паливу), саме на них припадає майже 74 \% загального обсягу споживання деревної тріски і 76 \% загального об'єму споживання гранул. Тому рекомендується встановити поріг потужності таким чином, що критерії сталості розповсюджуються тільки на установки $\geq 20$ МВт (по паливу), що відповідає близько 6 $\mathrm{MBT}_{\mathrm{e}}$ та $17 \mathrm{MBT}_{\mathrm{r}}$. Це не стосується біогазових установок (поріг потужності має бути нижче) i до рідких біопалив (критерії сталості повинні перевірятися у всіх випадках).

- Визнати добровільні схеми сертифікації для твердих біопалив, якщо вони задовольняють вимогам Єврокомісії, за аналогією з добровільними 
схемами сертифікації для рідких біопалив.

\section{Ситуація в Україні}

В Україні питання сталого розвитку біоенергетики знаходиться ще на доволі ранній стадії обговорення, усвідомлення та практичної реалізації. Але проблема виконання критеріїв сталості може стати нагальною у разі експорту біопалив або сировини для їх виробництва у СС, а також у подальшому процесі євроінтеграції. Це питання $\epsilon$ актуальним для країни вже зараз 3 огляду на необхідність виконання національної індикативної цілі по використанню ВДЕ у транспортному секторі - 10 \% у 2020 році згідно Національного плану дій з відновлюваної енергетики на період до 2020 року [14]. До виконання цієї цілі мають враховуватися тільки біопалива, вироблені 3 дотриманням критеріїв сталості. Треба зазначити, що у НПДВЕ вказано, що у кількісній оцінці очікуваного обсягу споживання ВДЕ на транспорті враховано біопалива, що відповідають критеріям сталості. Але ці критерії в даному документі не деталізовані, і не включено в явному вигляді вимогу про те, що для зарахування у виконання цілі 2020 року біопалива обов'язково мають відповідати критеріям сталості. Вважаємо, що цей законодавчий пробіл має бути заповнений.

У 2014 році в Україні, як члені Енергетичного Співтовариства, було розроблено і затверджено План заходів з імплементації Директиви 2009/28/ ЄС [15], який, серед іншого, включає наступні пункти:

- Розробити і забезпечити оприлюднення на офіційних веб-сайтах Мінприроди, Держекоінвестагентства та Держенергоефективності методики проведення розрахунку показників скорочення обсягів викидів парникових газів для біопалив та біорідин.

- Розробити технічні вимоги до виробництва і використання біопалив та біорідин із скороченням обсягів викидів парникових газів, починаючи $з$ 01.01.2017, не менш як на $50 \%$, а 3 01.01.2018 - не менш як на 60 \% для біопалив та біорідин, вироблених на установках, введених в експлуатацію після 1 січня 2017 року.

- Розробити критерії сталості для рідкого та газоподібного палива, що виробляється з біомаси та використовується на транспорті, а також для рідкого палива, що виробляється з біомаси та призначається для енергетичного використання, іншого ніж транспорт, враховуючи виробництво електричної, теплової енергії та енергії на охолодження.

Критерії сталості для рідкого та газоподібного палива і для біорідин ще й досі знаходяться в процесі розробки, хоча згідно вищезазначеного Плану заходів це мало бути зроблено до кінця $2014 \mathrm{p}$.

3 огляду на зазначене вище, вважаємо за необхідне:

1. Суттєво прискорити роботи по виконанню всіх пунктів Плану заходів 3 імплементації Директиви 2009/28/СС, що стосуються аспектів сталості біоенергетики.

2. Розробити національну систему верифікації біопалив на відповідність критеріям сталості або прийняти (адаптувати) для використання в Україні одну з існуючих систем добровільної сертифікації, визнаних Європейською Комісією.

3. Уповноваженим органам відслідковувати політику Свросоюзу щодо сталого розвитку сектору біоенергетики, оприлюднювати інформацію на їх офіційних веб-сайтах і оперативно реагувати шляхом розробки відповідних нормативних документів в Україні.

\section{Висновки}

В Європейському Союзі приділяється велика увага питанню сталого розвитку біоенергетики 3 акцентом на забезпечення сталого отримання біомасової сировини для виробництва біопалив та енергії. Деякі вимоги щодо цього вже $\epsilon$ обов'язковими для країн ЄС (виробництво рідких біопалив та біорідин для можливості зарахування у виконання цілі 2020 року по використанню ВДЕ на транспорті та для отримання фінансової підтримки), інші ще носять рекомендаційний характер (виробництво електричної енергії, теплової енергії та холоду 3 твердої та газоподібної біомаси). Загалом спостерігається тенденція поступового посилення вимог щодо виконання критеріїв сталості.

В Україні питання сталого розвитку біоенергетики знаходиться ще на доволі ранній стадії практичної реалізації. Хоча в країні $є$ організації, уповноважені виконувати 
сертифікацію сталості біопалив по добровільним схемам, визнаним Єврокомісією, їх послугами наразі користується дуже мала кількість компаній. Але проблема виконання критеріїв сталості може стати нагальною у разі експорту біопалив або сировини для їх виробництва у СС, а також у подальшому процесі євроінтеграції. Це питання $\epsilon$ актуальним для країни вже зараз 3 огляду на необхідність виконання національної індикативної цілі по використанню ВДЕ у транспортному секторі - 10 \% у 2020 році згідно Національному плану дій з відновлюваної енергетики на період до 2020 року. Вважаємо за необхідне суттєво прискорити в Україні роботи по виконанню всіх пунктів Плану заходів 3 імплементації Директиви 2009/28/СС, що стосуються аспектів сталості біоенергетики.

\section{ЛІТЕРАТУРА}

1. Report of the World Commission on Environment and Development: Our Common Future, March 1987

http://www.un-documents.net/our-common-future. pdf

2. Plan of Implementation of the World Summit on Sustainable Development

http://www.un.org/esa/sustdev/documents/WSSD_ POI PD/English/WSSD PlanImpl.pdf

$\overline{3}$. Directive $2009 / 2 \overline{8} / E C$

http://eur-lex.europa.eu/legal-content/EN/TXT/PDF /?uri=CELEX:32009L0028\& from $=\mathrm{EN}$

4. Directive (EU) 2015/1513 http://eur-lex.europa.eu/legal-content/EN/TXT/PDF /?uri=OJ:L:2015:239:FULL\&from=EN

5. Directive 2009/30/EC http://eur-lex.europa.eu/legal-content/EN/TXT/PDF /?uri=CELEX:32009L0030\& from $=\mathrm{EN}$

6. Sustainability Criteria for Biofuels: Report for Ukraine. E4tech (UK) for the European Energy Community Secre-tariat, 2015

https://www.energy-community.org/portal/page/
portal/ENC HOME/DOCS/3606186/0F835C17E1 B230B4E053C92FA8C00871.PDF

\section{Voluntary schemes}

https://ec.europa.eu/energy/en/topics/renewableenergy/biofuels/voluntary-schemes

8. Методичні рекомендації щодо визначення критеріїв сталості виробництва біомаси, 2015. http://minagro.gov.ua/node/17694

9. Стандарm EN 16214

http://standards.globalspec.com/standards/detail?fa milyId=ZYGPGDAAAAAAAAAA

10. Report on sustainability requirements for the use of solid and gaseous biomass sources in electricity, heating and cooling $\operatorname{COM}(2010) 11$ final, 25.2.2010

http://eur-lex.europa.eu/legal-content/EN/TXT/PDF /?uri=CELEX:52010DC0011\&from $=\mathrm{EN}$

11. GBEP Sustainability Indicators for Bioenergy http://www.globalbioenergy.org/fileadmin/ templates/gbep/images/Ylenia/Summary table website 12-11.pdf

12. Biomass for electricity and heating Opportunities and challenges, European Parliament, 2015

http://www.europarl.europa.eu/RegData/ e tu d e s / B R I E / $2015 / 568329$ / E P R S BRI\%282015\%29568329_EN.pdf

13. AEBIOM position on "A sustainable bioenergy policy for the period after 2020"

h t tp: //www.a ebi om.org/wp-content/ uploads/2016/05/AEBIOM-position-on-asustainable-bioenergy-policy-for-the-periodafter-2020-10.05.16.pdf

14. Національний план дій з відновлюваної енергетики на період до 2020 року. Затверджений Розпорядженням КМУ від 01.10.2014 № 902-p.

15. Розпорядження КМУ від 03.09.2014 №791-p «Про затвердження плану заходів 3 імплементації Директиви Європейського Парламенту та Ради 2009/28/СС». 


\section{ANALYSIS OF CRITERIA FOR THE SUSTAINABLE DEVELOPMENT OF BIOENERGY}

\author{
Geletukha G.G., Zheliezna T.A., Tryboi O.V., \\ Bashtovyi A.I.
}

Institute of Engineering Thermophysics of the National Academy of Sciences of Ukraine, vul. Zhelyabova, 2a, Kyiv, 03680, Ukraine

EU sustainability criteria for the production and consumption of biofuels are analyzed. The paper reviews current EU policy on sustainable bioenergy and future plans. It is shown that general trend is appearance of wider and stricter requirements for the sustainability of biofuels. Directive 2009/28/ EC sets a mandatory $10 \%$ minimum target to be achieved by all Member States for the share of renewables in transport sector by 2020. Biofuels used for compliance with the targets laid down in the Directive, and those that benefit from national support schemes, should therefore be required to fulfil sustainability criteria. In 2015, the European Commission announced that a new directive on renewable energy, which includes targets for all EU countries for the period 2020-2030, will be issued by early 2017 . One of the aims is to introduce bioenergy sustainability policy. In Ukraine, the issue of sustainable bioenergy development is still at a relatively early stage of discussion, understanding and implementation. Moreover, the sector of liquid biofuels generally develops very slowly. But the issue of sustainability criteria may become urgent in the case of export of biofuels or raw materials for their production to the EU and in the further process of European integration. For Ukraine, it is recommended to significantly accelerate the work on the realization of all points of the Action Plan for the implementation of Directive 2009/28/EC related to the aspects of bioenergy sustainability.

References 15.

Key words: sustainable development, sustainability criteria, bioenergy, biomass, solid biofuel, liquid biofuel

1. Report of the World Commission on Environment and Development: Our Common
Future, March 1987

http://www.un-documents.net/our-common-future. pdf

2. Plan of Implementation of the World Summit on Sustainable Development http://www.un.org/esa/sustdev/documents/WSSD_ POI_PD/English/WSSD_PlanImpl.pdf

$\overline{3}$. Directive $2009 / 2 \overline{8} / E C$

http://eur-lex.europa.eu/legal-content/EN/TXT/PDF /?uri=CELEX:32009L0028\&from $=\mathrm{EN}$

4. Directive (EU) 2015/1513

http://eur-lex.europa.eu/legal-content/EN/TXT/PDF /?uri=OJ:L:2015:239:FULL\& from $=\mathrm{EN}$

5. Directive 2009/30/EC http://eurlex.europa.eu/legal-content/EN/TXT/PDF/ ?uri=CELEX:32009L0030\&from $=\mathrm{EN}$

6. Sustainability Criteria for Biofuels: Report for Ukraine. E4tech (UK) for the European Energy Community Secretariat, 2015

https://www.energy-communi-ty.org/portal/page/ portal/ENC HOME/DOCS/3606186/0F835C17E1 B230B4E053C92FA8C00871.PDF

7. Voluntary schemes https:/ec.europa.eu/ energy/en/topics/renewable-energy/biofuels/ voluntary-schemes

8. Methodological recommendations on criteria sustainability of biomass production, 2015.

http://minagro.gov.ua/node/17694

9. Standard EN 16214

http://standards.globalspec.com/standards/detail?fa milyId=ZYGPGDAAAAAAAAAA

10. Report on sustainability requirements for the use of solid and gaseous biomass sources in electricity, heating and cooling $\operatorname{COM}(2010) 11$ final, 25.2.2010

http://eur-lex.europa.eu/legal-content/EN/TXT/PDF /?uri=CELEX:52010DC0011\&from $=\mathrm{EN}$

11. GBEP Sustainability Indicators for Bioenergy http://www.globalbioenergy.org/fileadmin/ templates/gbep/images/Ylenia/Summary_table website_12-11.pdf

12. Biomass for electricity and heating Opportunities and challenges, European Parliament, 2015

http://www.europarl.europa.eu/RegData/ e tudes/B R I E / 2015 / 568329 / E P R S BRI\%282015\%29568329_EN.pdf

13. AEBIOM position on «A sustainable 
bioenergy policy for the period after 2020»

h t t p://www.a ebi om.org/wp-content/ uploads/2016/05/AEBIOM-position-on-asustainable-bioenergy-policy-for-the-periodafter-2020-10.05.16.pdf

14. National renewable energy action plan up to 2020. Approved by the Cabinet of Ministers of
Ukraine Executive Order No. 902-p of 1 October 2014.

15. Cabinet of Ministers of Ukraine Executive Order No. 791-p of 3 September «On the approval of the action plan for the implementation of the Directive of European Parliament and Council 2009/28/EC»

Получено 08.09.2016 Received 08.09.2016 